\title{
CÓMO NACIERON LOS CINES
}

Aurelio de los Reyes

Es lugar común despreciar y subestimar los cines, incluso negarles cualidades artísticas. Sin embargo, debido al gusto del público por el espectáculo, proliferaron desde pocos años después de las primeras exhibiciones cinematográficas en 1896. Adoptaron una forma peculiar derivada de los teatros, de los que heredar on ciertas características, aunque la influencia no fue siempre directa. El espectáculo mismo obligó a los arquitectos o proyectistas a introducir por lo menos dos elementos ajenos a la tradición teatral: la pantalla y la caseta de proyección, de tal manera que ambos resultan por completo fuera de lugar en el sinnúmero de teatros adaptados para funciones cinematográficas, según lo atestiguan viejas fotografías de los teatros Morelos de Aguascalientes, Calderón de Zacatecas o el Circo-Teatro Orrin de la ciudad de México, por citar unos ejemplos. La caseta de proyección, colocada en el palco central del anfiteatro, rompe la unidad deseada por los autores del proyecto arquitectónico (figura 1).

Por otra parte, cuando se inició la fiebre cinematografica allá por 1906, la competencia obligó a los empresarios a ofrecer al público mayores comodidades y atractivos. Los proyectistas enriquecieron la decoración y aumentaron los servicios paulatinamente (W.C, dulcería, vestíbulo, pórtico); dieron mayor importancia a la primera, que por supuesto no escapó a las influencias de las diversas corrientes que han conformado la cultura mexicana, y asi tenemos informes de que hubo salones cuyo interior era en el más puro estilo artnouveau, como el Cine Club de Jorge Alcalde en las calles de 5 de Mayo y Motolinía, actualmente convertido en tiendas de ropa que borraron todo vestigio de su or namentación; conocemos las fachadas de dos viejos cines, o "salonesteatro", como se les solía llamar, de la primera década del siglo, uno en las calles de Jesús Carranza construído bajo el inf́lujo del clasicismo francés, el otro en la colonia Santa María que sobresale por su sobriedad y por la calidad del trabajo de los hierros forjados de su marquesina. Una tercera fachada antigua sería la del cine Olimpia, construida en 1919, pero en la actualidad cubierta por una falsa fachada, como si los propietarios se avergonzaran de poseer un edificio cuya cara era similar a la del teatro Esperanza Iris, hoy Teatro de la Ciudad de México.

Hubo también cines en estilo art-deco, de los que sobreviven algunos que conservan ciertas características, el Máximo (a punto de ser demolido), el Florida, el Teresa, el Lido (hoy Bella Época), el Hipódromo y el Gloria; los hubo en estilo neocolonial, como el Alameda (en proceso para ser adaptado a teatro), el Lindavista y el Colonial, que por milagro conservan sus características originales; en neoazteca, el cine Azteca, ya demolido; o en seudo estilos indígenas (figura 2), como el Janitzio, recientemente derribado por las obras de 
ampliación del metro, y el remozado cine Mitla, que obedecen a la búsqueda de una expresión mexicanista en la arquitectura, la pintura y la escultura.

Otros cines fueron proyectados conforme al concepto que en México se ha tenido del cine, el de ser un espectáculo para divertir, distraer, para soñar con quimeras inalcanzables; el de ser un pretexto que estimule la fuga de la realidad de los espectadores. $Y$ así, algunos emulan palacios europeos con mármoles, grandes arañas, alfombras, escaleras, estatuas, pinturas y espejos monumentales que nos remiten a Versalles o a mansiones en el estilo de los luises de Francia. Parece adivinarse el deseo de sus autores de comunicar una grandiosidad que en su vida cotidiana los asistentes están muy lejos de alcanzar. La arquitectura se integra al escapismo del público, que es envuelto en una irrealidad desde el primer paso que da dentro del salón. La película hace el resto: llevarlo de la mano a través de un viaje por mundos imposibles, o casi Quizá el ejemplo de una función "perfecta" lo fue la exhibición de Maria Isabel en el cine Roble; en las taquillas se formaron enormes "colas" y tumultos de sirvientas acompañadas por colegas, por su novio o por familiares que asistieron para soñar con las "glorias" de María Isabel, para festejar sus gracias y sus ocurrencias, y para admirar a la sirvienta que reunió las cualidades para conquistar al patrón, prohombre de negocios. $\mathrm{Y}$ eran de oirse las risas y los suspiros, y de verse las emociones, sufrimientos y lágrimas, a pesar de que ya conocían la historia por haberla leído, primero en la fotonovela Lágrimas, risas y amor, y luego visto en su versión de telenovela. A este tipo de cines pertenecen, además del cine Roble en demolición, el Real cinema, el Ópera, el Chapultepec, en cierta medida el cine México, y el Metropólitan, cuyo vestibulo tan ambicioso es el escenario ideal para la celebración de los quince años de una adolescente en el más puro estilo mexicano: hasta había un piano blanco; las escalinatas son perfectas para el descendimiento de la festejada acompañada por su galán, sus damas y chambelanes a los acordes de la marcha triunfal de Aída, enmedio de los efectos del hielo seco. Los espejos, damascos, candiles, alfombras, estucos con grutescos renacentistas, las estatuas, las pinturas y el mobiliario completan el cuadro; es como un set cinematográfico.

En fin, que si la ciudad de México tuvo fama el siglo pasado por la belleza de sus edificios, hacia 1911 se le llamó la Ciudad de los Cinematógrafos porque los había en todos lados, aunque algunos no fueran precisamente bellos y cómodos.

Su destrucción ha sido despiadada por diversos motivos: en primer lugar porque las grandes salas han caído en desuso porque el público se ha retirado del espectáculo (ignoramos las razones) y como por lo general se situaban en el corázón de las ciudades, el terreno era sumamente valioso y conservarlos como reliquia resultaba punto menos que incosteable para sus propietarios En segundo lugar por la obra de restauración de las ciudades, deseosas de preservar su pasado colonial, pero tal deseo ha sido miope porque se han destruído obras que han sido expresiones de la cultura nacional, de la que no debemos avergonzarnos en ninguna de sus manifestaciones. Tal el caso del cine 
Azteca de San Luis Potosí (figura 3), cuyo solar, además, quedó hueco, pues no se supo cómo suplirlo u otro cine en la ciudad de Pachuca, de estilo art-deco, que ocupaba una manzana y que bien visto era de los pocos cines concebidos como una unidad armoniosa, pues en su derredor se construyeron locales homogéneos para tiendas al menudeo; es decir, no era el "elefante blanco" incrustado en medio de otras casas como el citado cine Azteca o el cine Máximo de la ciudad de México.

Otros agentes de la destrucción han sido los temblores, que al menos en la ciudad de México han justificado la demolición de los cines Roble, Encanto, Palacio, Parisiana y Coliseo, entre otros muchos; la reciente moda de las salas pequeñas con el sacrificio de las grandes que albergaban multitudes: los cines Palacio Chino, Pathé, Morelia, Majestic y Bondojito; la remodelación de las ciudades, que en el Distrito Federal cobró sus víctimas en el viejo teatro Díaz de León, en las calles de Aztecas en el corazón de Tepito, en el Salón Santos Degollado y en los cines Casino (figura 4), Janitzio, Cairo y tantos y tantos otros más. Creemos que el estudio de la decoración de los cines es un magnífico complemento de las investigaciones sobre las diversas corrientes o estilos artísticos que de alguna manera han influído en la cultura mexicana; o bien sobre la cultura popular, por lo que no debemos subestimarla, así a veces nos moleste y resulte chocante a nuestra vista.

Ahora bien, el tamaño de las salas abiertas durante la primera década del siglo contrasta con la monumentalidad de las abiertas en los treintas o la década de los cincuentas, del cine Las Flores (1909) al cine Máximo (1930) y al cine Internacional (1959) con capacidad para cuatro mil espectadores. En la observación de sus fáchadas vemos que contrastan, además dos elementos, las taquillas y el pórtico. Los primeros cines escasamente incluyeron ambos elementos; por lo general improvisaban las primeras en el balcón de una casa y el segundo fue obligatorio a partir de 1911 para proteger a los espectadores que se arremolinaban en los expendios de boletos y en las puertas de entrada para protegerse de las inclemencias del tiempo, del viento, del frío o de la lluvia. Son de herencia teatral, según los vemos en los teatros Juárez de Guanajuato, Calderón de Zacatecas, La Paz de San Luis Potosí (figura 5), Degollado de Guadalajara o Morelos de Aguascalientes (figura 6), pero llegaron a los cines a través de disposiciones de las autoridades, pues tal vez la voracidad de los empresarios cinematográficos hizo que por lo general no fueran tomados en cuenta por los arquitectos de las primeras salas, quienes se preocuparon más por la ornamentación. Quizá los consideraron elementos muertos que desperdiciaban espacio. La voracidad fue tal que según noticias periodísticas, las primeras salas carecieron de excusados, con las consiguientes molestias para el público. Curiosamente, la ausencia de servicios en algunas se compensó con la riqueza del decorado de su fachada y de su interior.

Vale la pena, pues, que tratemos de seguir paso a paso cómo se conlor maron las salas cinematográficas.

Los enviados de Lumiére llegaron a México a tines de julio de 1896 y de in- 
mediato se dieron a la búsqueda de un local para sus exhibiciones, mismo que encontraron en el entresuelo de la Droguería Plateros de la segunda calle de Plateros 9, a espaldas de la joyería La Esmeralda, era el que ocupaba la bolsa de valores de México. Según el periódico El Siglo XIX, las primeras funciones tuvieron lugar después que el sitio fue "convenientemente arreglado" "Ignoramos en qué consistieron los arreglos. Tal vez se pintó y despejó de obstáculos para colocar libremente 30 o 40 asientos en hileras frente a la pantalla de una manera similar a un teatro de cámara, con la diferencia de que no había escenario. El "cuadro de albura uniforme y limpia" fue puesto en uno de los extremos para recibir el "haz luminoso" que desde el lado opuesto lanzaba el proyector En algunos lugares la pantalla fue colocada a la mitad del salón y los asientos a ambos lados, de tal manera que una mitad de los espectadores veía correctamente las imágenes, mientras que la otra mitad las veía al revés. Tal cosa fue obligada por las dimensiones de la sala, pues los proyectores no estaban tan perfeccionados como para ofrecer imágenes nitidas en locales grandes, aunque después fue un arbitrio utilizado por los empresarios: a los espectadores situados al frente de la pantalla les cobraron más el précio del boleto que a los que estaban detrás, quienes veían los letreros (cuando fueron de uso obligatorio en las películas a partir de 1906) en sentido inverso, y sólo contemplaban las sombra proyectada en la pantalla y escuchaban las voces de los artistas que en los intermedios ejecutaban algún número de variedad.

Las primeras funciones cinematográficas se llevaron a cabo en ese primer local durante los meses de agosto y septiembre de 1896. En octubre, los enviados de Lumiére fueron a Guadalajara, y al igual que en la ciudad de México, adaptaron un local para sus proyecciones en el Liceo de Varones en el exconvento de San José, actual museo del estado. De regreso a la ciudad de México ocuparon una accesoria en las calles del Espíritu Santo 4 en los bajos del Hotel de la Gran Sociedad (después Casa Bóker, hoy una sucursal de las tiendas Sanborn's). El salón era "espacioso y tapizado con elegancia, como a la mitad del mismo y hacia el costado que ve al norte se encuentra colocado el aparato que proyecta su poderoso haz de luz sobre un cuadrado lienzo blanco, situado en el extremo que ve al oriente."'

Mientras tanto, los representantes de Thomas Alva Edison ofrecieron exhibiciones del Vitascopio, símil del cinematógrafo Lumiére, con poca fortuna, en el teatro-circo Orrin de la plazuela de Villamil (actual teatro Blanquita). Al poco tiempo cambiaron a un local cuyos propietarios alquilaban para oficinas, y tal vez para bodegas, en las calles de la Profesa 6 (actualmente Madero, a un costado de la Iglesia del mismo nombre), y abrieron al público "un decente saloncito" acondicionado para el caso.

El aparato fue "Correctamente montado y manejado con suma propiedad, no se notan en él los defectos de afocación que se notaban en el teatro Orrin, las

"Cinematógrafo Lumière". El siglo .MY, agosto I de 1890, p I

2 "El cinematógralo Lumière." K/ Vaconal, viernes 27 de noviembre de 1896, p 2 
figuras se destacan con claridad" " La competencia hizo que la agencia Edison ofreciera por el mismo precio espectáculos adicionales, para lo que se adaptaron otras dependencias de la casa-habitación, en una, los espectadores veían el Vitascopio, en otra escuchaban y admiraban al kinetófono y en una tercera veían el floroscopio o rayos $\mathrm{X}^{4}$

Durante los dos años siguientes, 1897 y 1898, el cine continuó viviendo de prestado, en la ciudad de México en el vestíbulo del teatro Nacional, en el sam lón del Staking Rink, en los bajos del hotel Gillow. Y en el interior del país, en los teatros municipales. Y es que el suministro de películas nuevas por parte de los productores extranjeros era lento y el público se cansaba pronto del escaso repertorio de los empresarios, y los obligaba a realizar temporadas cortas en un mismo lugar. Por lo tanto éstos no invertían en una construcción específica para su espectáculo. Hacia 1899 se abrió una tienda para vender y alquilar películas y la ciudad de México vio la multiplicación de saloncillos, de carpas y de jacalones - construcciones rústicas de tablas y láminas de cartónpara exhibiciones cinematográficas. Hubo veintitantos esparcidos por la metrópoli, la mayoría en el barrio de la Merced. Centremos nuestra atención en los locales de "cal y canto", pues son los que generarán las salas cinematográficas. La competencia entre los empresarios hizo que contrataran orquestas e introdujeran las variedades para amenizar los intermedios. De esa manera se inició la construcción o adaptación de saloncillos que debían poseer, además de la consabida pantalla para la proyección de películas, un pequeño escenario, que más que escenario consistió en un tapanco, que nada tenía qué ver con un escenario según el modelo de los teatros mexicanos, el Nacional, del Arbeu, del Principal, del Hidalgo y de los teatros municipales del interior de la República El primero que reunió tales modalidades parece que fue el salón de Variedades en las calles del Coliseo Nuevo 5 (hoy Bolívar), frente al teatro Principal, ${ }^{5}$ y en el que también se construyó una cantina para la venta de aguas gaseosas y golosinas, antecedente de los expendios de dulces en los vestíbulos de las actuales salas cinematográficas.

La primera caseta de proyección de que tengo noticias fue construida el año 1900 en la Escuela Nacional Preparatoria, en un salón acondicionado para proyectar peliculas para ilustrar clases de historia; dicho salón estaba situado en el piso bajo y era de doce metros de largo por cinco de ancho y otros tantos de altura; en la parte posterior y "a una altura de dos metros, queda la plataforma aérea que se va a utilizar para la colocación de los aparatos científicos" que desaparecería "entre los cortinajes negros que la envuelven perforados para que pase la luz, que se refleja en una pared del frente que es enteramente blanca" "Sin embargo, la caseta no fue construída para aislar el proyector y

3 "Gacetilla" Datolo del Hogar, jueves 22 de octubre de 1896, p. 2.

+ Idem

3 "Espectáculo moderno" El Chusme, miércoles 19 de abril de 1899, p 3

"Información La loz de Méxuco, viernes 20 de marzo de 1900, p.p 2 y 3 
las películas del público con el fin de evitar los peligros de un incendio, sino para evitar a los espectadores las molestias causadas por la luz que emanaba del proyector. El tipo de material utilizado (tela) hacía doblemente peligroso el riesgo de un siniestro, ya que las películas eran sumamente combustibles; en ocasiones bastaba una fricción fuerte para que surgieran las llamas. (Para estas fechas, la prensa ya había registrado varios incendios, algunos de consideración, como el ocurrido en el teatro Principal de Guanajuato donde una señora quedó completamente desnuda por la precipitación con que los espectadores salieron a la calle)

Para diciembre de 1900 sólo quedaban dos saloncillos para proyecciones cinematográficas. Los demás fueron clausurados o cerrados por los empresarios obligados por el Ayuntamiento. No hay noticia de que alguno de los locales contara con el indispensable servicio sanitario ni con ventilación apropiada o con puertas para un rápido desalojo en caso de incendio.

Los empresarios se fueron por el interior del país con su proyector, sus películas y sus empleados a correr la legua y durante algunos años darían funciones preferentemente en los teatros municipales. Por excepción en alguna ciudad se construirian locales para proyecciones cinematográficas. Tal es el caso de una salita abierta en abril de 1901, en la ciudad de Orizaba, en la segunda calle del Calvario, ${ }^{7}$ para exhibir vistas estereoscópicas, pero cerrada al poco tiempo. Tres meses después Francisco Sotarriba inauguró en la misma ciudad un "salón-teatro" para exhibir peliculas "parlantes" de tema mexicano, mediante la combinación de cine con fonógrafo, en la primera calle del 5 de Mayo No. 3. Se dijo que fue un local cómodo y decorado "con elegancia y propiedad, como nunca lo habiamos visto en Orizaba, al grado de que no desluciría en las calles de Plateros o San Francisco de la capital de la República" 8 En ésta, mientras tanto, los escasos empresarios que la visitaron continuaron sus funciones en los sitios ya habituales: en el circo-teatro Orrin de la plazuela de Villamil, en las salas de los bajos del Hotel Gillow y de espera del teatro Riva Palacio (que era una casa adaptada) (figura 7), en el teatro Renacimiento, etcétera La excepción fue Enrique Moulinié que acondicionó la casa de la testamentaría Lerdo de Tejada en las calles del Coliseo Viejo 15 (hoy 16 de Septiembre, en la papelería La Helvetia), para ofrecer funciones de cine combinadas con variedades. Entre las novedades que construyó en relación con los sitios precedentes, estaba el acondicionamiento de una ventana a la calle como taquilla, y la de que no fue una recámara la que sirvió para salón de proyección, sino el patio, debidamente techado con su seudo-escenario al fondo para los números de music-hall. Las multitudes gustaban ya del espectáculo y los sitios reducidos eran insuficientes para albergarlas. Moulinié con su familia ocupó una parte de la finca como habitación mientras que en la otra

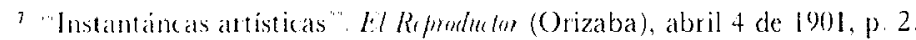

"Lhm l:l (wmmpulalu, (Orizaba) agosto 25 de $1901, \mathrm{p} 2$ 
ofreció diversos espectáculos, un museo de cera, trucos ópticos, máquinas traganíqueles, etc. Bautizó su negocio con el nombre de El Palacio Encantado porque su fachada la iluminó con multitud de focos eléctricos que producían un efecto fantástico, y porque su interior lo decoró profusamente Ignoramos de dónde tómo la idea de iluminar la fachada, si de Francia o de los Estados Unidos o fue una idea original. Iniciábase la utilización de las marquesinas, otro elemento característico de los cines y que en algunos llegaron a ser prodigios de decoración; en otros, los arquitectos le dieron tanta importancia que la convirtieron en sustituto del pórtico, como es el caso del actual cine Teresa, verdadero alarde de ingenio para aprovechar al máximo el solar a costa de la banqueta pública.

Otras novedades que ofreció Moulinié al público fue la de su esposa proyectando películas y sus hijos vendiendo boletos y explicando de viva voz el significado de las vistas fijas o de movimientos exhibidas

Federico Bouvi en Aguascalientes hizo lo mismo que Moulinié en el Distrito Federal: acondicionar una casa-habitación para exhibiciones cinematográficas, el patio lo convirtió en sala de proyección en la que construyó con madera unas divisiones a manera de palcos (figuras 8 y 9). En las otras dependencias había salón de patinar, más diversiones, la taquilla y un "boudoir"'para que las señoras arreglaran "sus elegantes toilettes"; él con su familia ocupó la parte trasera de la finca.

Hasta 1906 se inició en la ciudad de México la construcción de locales para proyecciones cinematográficas, que en principio volvian a repetir las características del salón de Variedades abierto en 1899. Y es que la apertura de distribuidoras que surtieron con mayor frecuencia películas nuevas permitió la sedentarización de los empresarios; las salas se multiplicaron por arte de magia.

Donde quiera que se desocupaba un local céntrico y con puertas a la calle se abría un salón de cinematógrafo, para el cual bastaban unas filas de sillas y una pantalla en que se reflejaban las vistas; un piano o una pequeña orquesta completaban el ajuar indispensable para el caso .... Los titulados Salón Rojo y Montecarlo vinieron a convertirse en teatrillos de variedades, que alternando con las vistas de cinematógrafo, distraían a su público con prestidigitadoras, transformistas, coupletistas y bailarines, no faltos de mérito 9

El primero fue el salón La Boîte en la calle de San Juan de Letrán cinco y medio, abierto en febrero de 1906 y que con anterioridad había sido cantina. Felipe de Jesús Haro lo adaptó, pintó, decoró, e iluminó adecuadamente. Otro más fue el que Salvador Toscano abrió en marzo en la esquina de las calles de San Francisco y Coliseo Nuevo (Madero y Bolivar) en el edificio Borda,

\footnotetext{
"Enrique de Olavarría y Ferrari, Reseña Histórica del teatro en México. México, 2a ed Porrúa, 1961 , p. 2907
} 
que se convertiría más tarde en el celebrado Salón Rojo. Ambos locales, La Boîte y el de loscano, comunicaban a la calle con varias puertas, no tenían vestíbulo ni pórtico ni sala de espera para que los espectadores "enfriaran" los ojos antes de salir a la calle o para que esperaran la salida del público para entrar a la siguiente tanda (figura 10). El Ayuntamiento ordenó a Toscano construír un "gabinete adecuado, con material incombustible" para los proyectores, y que el salón estuviera conectado a la calle por tres puertas que abrieran para afuera para facilitar una salida violenta del público en caso de incendio, ${ }^{10}$ pero como las puertas ya estaban construídas y abrían para adentro, exigió que durante las funciones permanecieran abiertas mientras que unas cortinas cubrieran los claros, lo que dio al salón una ventilación adecuada. Por un tiempo obligó a los empresarios a mantener las puertas abiertas durante la función hasta que construyeron sistemas de ventilación apropiados (aunque no siempre funcionaron). En junio Ignacio Yáñez solicitó permiso para abrir un salón en la tercera calle de Santa María la Ribera (actual cine Rívoli) que contaría con tres puertas a la calle, una para la entrada del público, otra para su salida y una tercera para seguridad, una caseta de proyección forrada de manta haría las veces de expendio de boletos; ofreció instalar en un patio "un excusado con todos los requisitos reglamentarios" "Y $\mathrm{Y}$ es que hasta ese mómento los sanitarios habían sido un problema en los locales improvisados para proyecciones cinematográficas, pues al principio las tandas eran de corta duración, de 15 a 20 minutos y los empresarios consideraron, tal vez, que los espectadores no experimentarían la necesidad de ir al baño o que, en todo caso, esperarían al fin de la función para en otro sitio satisfacer su necesidad Mas tal vez la concurrencia de niños que no controlaban suficientemente sus necesidades, pero sobre todo la prolongación de las funciones a una y dos horas de duración y la multiplicación de los concurrentes, los hizo instalar un excusado El problema fue que era de uso común para hombres y mujeres, aunque cada sexo iba por su lado, esperaba su turno Con seguridad el servicio consistía en un pozo sobre el que se colocaron tablas, la superior tendría más de dos agujeros para que otras tantas personas satisficieran su necesidao simultáneamente; no había clasificación sexista; quizá por lo mismo en esa época en las casas y en las viejas haciendas era familiar que más de dos personas fueran juntas "al común" y durante un buen rato comentaban los sucesos ordinarios de sus vidas La prensa comentó los nauseabundos olor es que invadian algunos cines

En noviembre de 1906 Jorge Alcalde, propietario de un salón en San José del Real 10, 11 y 12 (actual calle de Isabel la Católica), entre 5 de Mayo y Tacuba, ofreció un "salón de espera lujosamente amueblado, donde pueden caber cómodamente 500 personas. Magnífica cantina y un elegante gabinete para

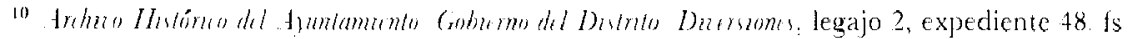
s.n., en adelante $1 \mathrm{HA}($ ( ; I) J)

11 Itrm. legajo 3. expediente 96, ts. s n 
señoras" 12 Las novedades eran la sala de espera o vestíbulo donde los espectadores "enfriaran" los ojos antes de salir a la calle, pues los periódicos hablaron de las infecciones a menudo ocasionadas por la abrupta salida al aire frío; y el gabinete para señoras, que no era el excusado seguramente anhelado, sino un lugar para arreglar los vestidos y sombreros después de la función. Finalmente, el Salón Mexicano de las calles del Empedradillo 10 ofreció "seguridad, moralidad y un W C para señoras".

Ahora bien, un mes antes, en octubre de 1906 se abrió la Academia Metropolitana en la plazuela de Santos Degollados (figuras 11, 12, 13 y 14) que asimilaría la experiencia de los treinta y tantos salones de cine construídos en el lapso de unos cuantos meses: poseía un pequeño pórtico y un vestíbulo, sanitarios, una luneta o patio amplio circundado por unos a manera de palcos, un pequeño escenario con su pantalla y una cantina en el primer piso, sobre el vestibulo, para vender refrescos, dulces, nieves y otras golosinas. La sala era un hibridismo entre un teatro de cámara y un gran teatro; era un sitio de uso múltiple, acorde con el término empleado para designarlo; "salón-teatro", pues estaba destinado no tan solo a la exhibición de películas; lo mismo servía para conciertos de música de cámara concurridos por la créme de la créme, que para bailes domingueros a los que no precisamente asistía lo "más granado de la sociedad". Servía asímismo para patinar, para recepciones familiares con motivo de bodas o días de santo, y los constructores tuvieron en cuenta tales inquietudes ${ }^{13}$ Más tarde, en el maderismo, atestiguaria asambleas obreras y reuniones de feministas para ayudar a los menesterosos. Es decir, sus elementos no fueron pensados para cumplir un sólo objetivo como los grandes teatros, que por excepción y quizá a pesar de ellos eran utilizados para los bailes suntuosos de la sociedad (véase por ejemplo la descripción que Federico Gamboa hace en su novela Santa de los bailes de carnaval en el teatro Arbeu a principios de siglo), para proyecciones cinematográficas u otros actos. Otros salones construídos con características similares a las de la Academia Metropolitana fueron el Bucareli Hall (actual cine Bucareli, transformado) el teatro Alcázar de las calles del Ayuntamiento 31 (demolido para abrir la prolongación de la calle de José María Marroqui (figuras 15, 16 y 17) y el teatro de la Taba* calera Mexicana. Estos dos últimos eran salas más ambiciosas y adoptaron escenario y palcos francamente teatrales. Comenzaba la institucionalización de los cines

De lo anterior concluimos que algunos cines adoptaron elementos teatrales (pórtico, vestíbulo, escenario) por necesidades intrínsecas, como soluciones pragmáticas; en cambio otros adoptaron características estrechamente ligadas a la teoría teatral, lo que dieron por resultado su hidridismo. En algunas ciudades los cines reemplazaron, más tarde, a los teatros municipales, que por lo general fueron abandonados a su suerte después que el público asistente a

"Anuncio". II Impraral jueves 8 de noviembre de 1906, p 8

"La Icademia Mletropolitana" Arle, latra, octubre de 1906, p s.n 
las funciones cinematográficas los destrozó En Aguascalientes, por ejemplo, el cine Colonial sustituyó al teatro Morelos y en Fresnillo, el cine México al teatro Echeverría.

Ahora bien, la caseta de proyección fue un elemento que los arquitectos tardaron en asimilar. Por lo menos hasta 1910 no la habían integrado adecuadamente al edificio. Era un mal necesario que los autores de la Academia Metropolitana no tomaron en cuenta (figuras 18 y 19) porque hasta 1907 el Ayuntamiento la hizo obligatoria ${ }^{14}$ debido a los sucesivos incendios con muertos y heridos. Tal obligatoriedad la hizo un elemento que rompió la armonía de las construcciones en que fue instalada. Uno de los primeros casos en que vemos el esfuerzo por integrarla es en el teatro Alcázar (figura 20), pero con resultados desafortunados, pues resulta agresiva a los ojos del espectador además de que su poca altura hizo que, tal vez, fuera el blanco de los inoportunos para quienes fue fácil obstruir la proyección de películas al interponer la mano, un sombrero u otro objeto entre el proyector y la pantalla, por esto tuvo que construirse en un lugar lejos del alcance de los impertinentes.

En San Luis Potosí el empresario del Salón Pathé asimiló la experiencia metropolitana, y en una casa adaptada en lugar de ofrecer diversiones complementarias en las otras dependencias, las transformó en una vasta sala de espera, en una nevería y en un W.C. para señoras ${ }^{15}$ Para no quedarse atrás, el empresario del Salón París de la misma ciudad, hizo

de los dos anexos que tenía al frente, el salón de espera para el departamento de primera clase, al fondo .... se ha dispuesto un magnífico gabinete para señoras, donde pueden arreglar su tocado, pues tendrá todo lo necesario para el caso y además unos elegantes W.C. sistema inglés, cuya instalación se ha hecho con esmero ... por lo que toca a la seguridad, están perfectamente garantizados los concurrentes ... la caseta del manipulador .. está forrada de asbesto de lámina y se le dotará con una fuente de celis.

Además se colocaron tanques de agua sobre el techo del que se conectaron tubos que conducían agua a los sanitarios y a la caseta para extinguir incen$\operatorname{dios}^{16}$

Hasta mayo de 1911 el Ayuntamiento de la ciudad de México estableció los requisitos mínimos generales para cualquier salón de espectáculos, ${ }^{17}$ y a los empresarios los obligó a construir además del vestíbulo, del excusado, de las salidas de seguridad, de ventilar adecuadamente el lugar, y de la taquilla, un pórtico, "que permita la entrada de los carruajes, y si sui categoría fuere menor (es decir, cine), tendrán marquesina dispuesta de manera de resguardar

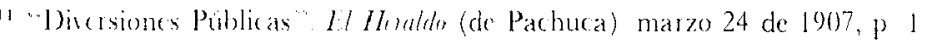

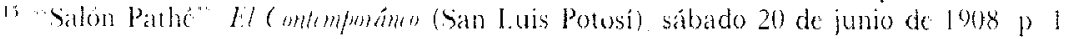

16 "Sakon Par is". Lem sabado 22 de agosto de loxs. p 3

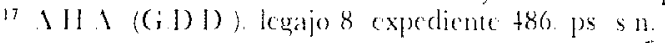


al público de la mejor manera posible. En todo caso, el pórtico y el vestíbulo tendrán la extensión suficiente para que sirvan de lugar de espera". Tal es el secreto de las dimensiones de las marquesinas de los cines Metropólitan, Maya, Florida y, como ya se dijo, del Teresa.

Ahora bien, la sociedad demandó tánto cine a lo largo de la revolución, sobre todo durante los años más difíciles, 1914, 1915 y 1916, que se construyeron locales cada vez más espaciosos, algunos de los cuales a simple vista daban la impresión de teatros, como el Alarcón o el Olimpia.

Los veintes agregaron un nuevo elemento: el espacioso vestíbulo del primer piso para efectuar concursos de bailè, de danzón, tango, foxtrot, etcétera, que tanto gustaron. El Salón Rojo y los cines Obrero Mundial y Olimpia adquirieron merecida fama por ellos; las competencias eran tan populares y tan reñidas que se veían concurridísimas por público de diversos sectores sociales El vestíbulo, por lo tanto, debía ser suficiente para albergar a la orquesta, a los concurrentes, a los espectadores y al jurado. Por supuesto que al pasar esa moda resultaron inútiles y los de los cines Olimpia, Bucareli, Venus y Coliseo fuer on aprovechados para levantar edificios de varios pisos para departamentos y para oficinas Quizá uno de los pocos que subsisten completos (si no es que es el único), es el del cine Florida, en el cual uno se siente empequeñecido por la dimensión del espacio. Los vestíbulos del Metropólitan, Chapultepec o Real Cinema apenas son recuerdo de sus predecesores y en cuanto a la forma están más ligados a la tradición teatral que a la cinematográfica.

\section{Epílogo}

Hoy parece que los cines regr esan a sus orígenes, a las pequeñas dimensiones, a las salas familiares, pero dotados con elementos mínimos, ya no son salas de uso múltiple sino exclusivamente cinematográfico, y así cuentan con un pequeño vestíbulo, taquilla, expendio de dulces, refrescos y golosinas, marquesina plegada sobre sí misma o excenta del edificio, en la banqueta, sostenida por soportes de fierro, y caseta de proyección en lugar adecuado, casi todos carecen de decoración llamativa, de escenario para variedades y de pórtico Eso sí, cuentan con sus respectivos W. C. "estilo inglés". Han dejado de ser "salonesteatro" para ser exclusivamente cines

La pequeñez ha ocasionado el aumento del precio de entrada y los cines populares han visto incrementar el precio del boleto de tres a 25 pesos y disminuir las películas exhibidas de tres a una y por excepción a dos; además, en varios se ha suprimido la permanencia voluntaria. Al igual que a su llegada cuando se cobró un peso por entrar (precio elevado en aquel entonces), el cine vuelve a ser un espectáculo para privilegiados ¿A dónde se desplaza el gran público que llenaba el Goya, el Alarcón, el Máximo, el Estrella, el Roxy, hoy desaparecidos? Quizá prefiera la televisión, pues las casas de las colonias proletarias lucen orgullosas su antena para el aparato receptor de las imágenes, y es que las telenovelas ofrecen el mismo espectáculo que un tiempo ofreció la 
DOI: http://dx.doi.org/10.22201/iie.18703062e.1982.50\%20Tomo\%202.1150

producción mexicana, consumida por ese público; pagar una cuenta de luz es desde luego más económico que asistir varias veces al cine en el transcurso de uno o dos meses. Y eso ha hecho que los grandes cines desaparezcan paulatinamente. Urge rescatar para el estudio de la cultura mexicana las características de los que aún permanecen en pie y que no tardarán en ser demolidos o transformados 


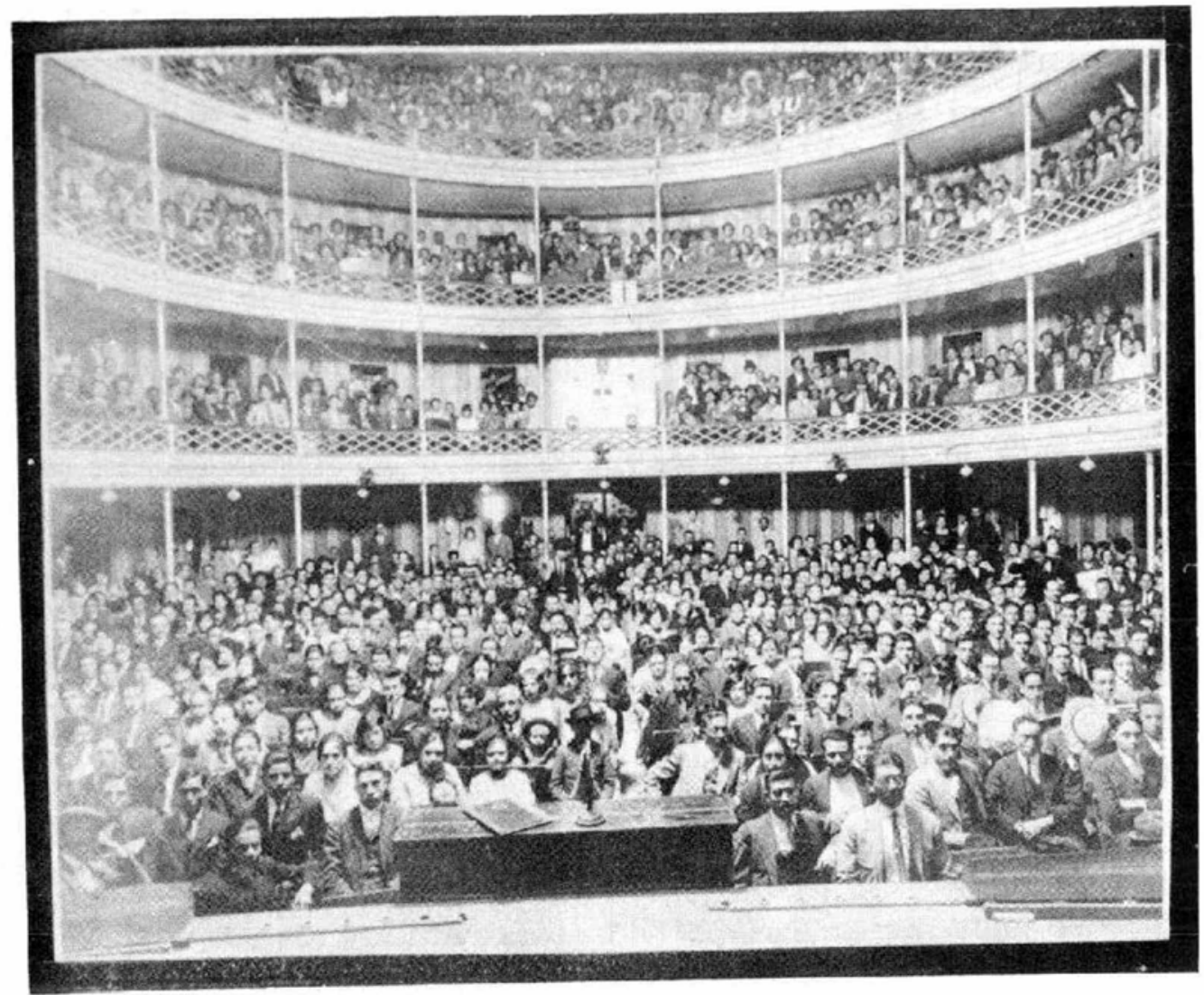

Figura 1. Aguascalientes, Ags., teatro Morelos. Obsérvese cómo la caseta de proyecciones, en los palcos primeros, rompe la unidad arquitectónica. 


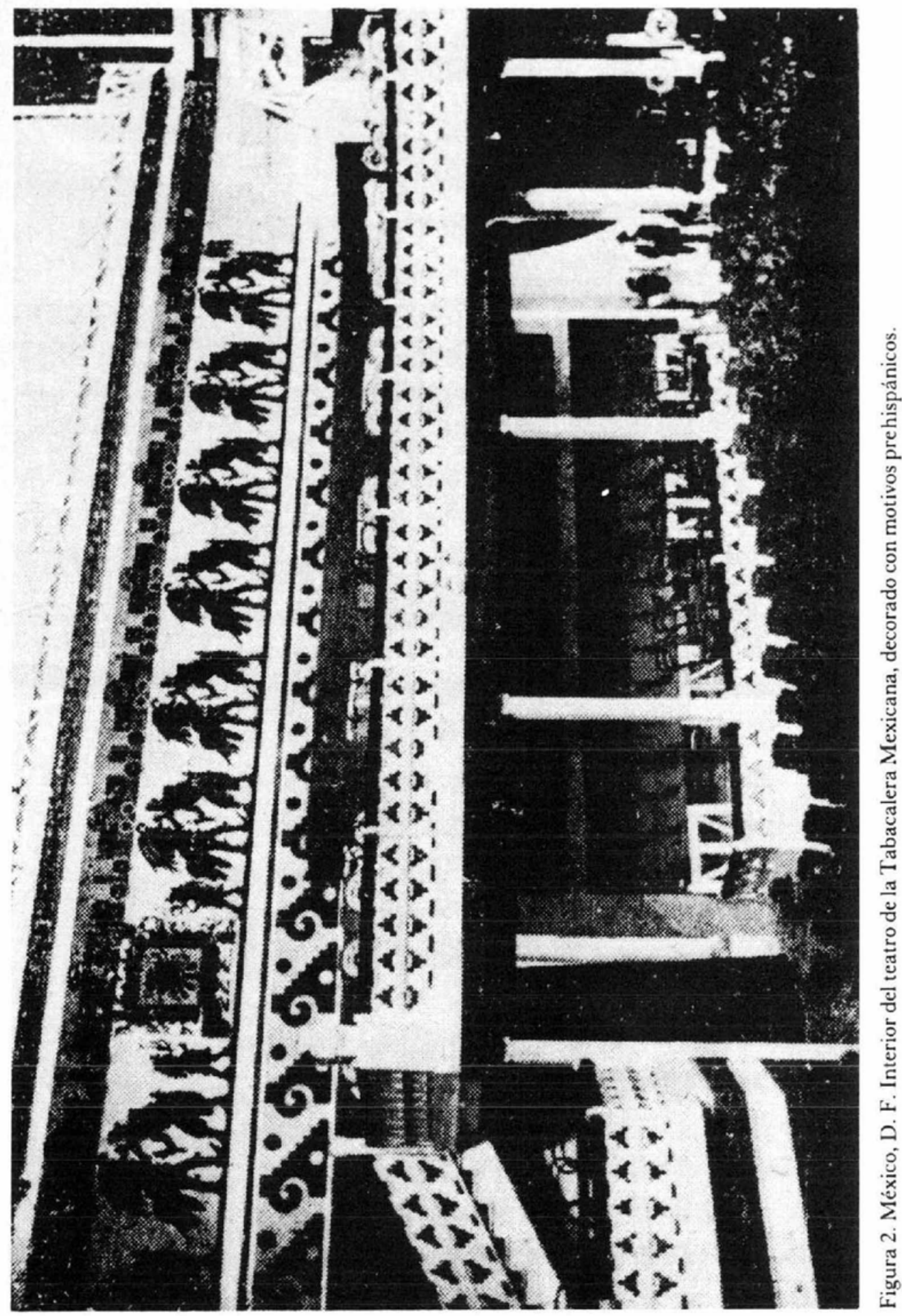




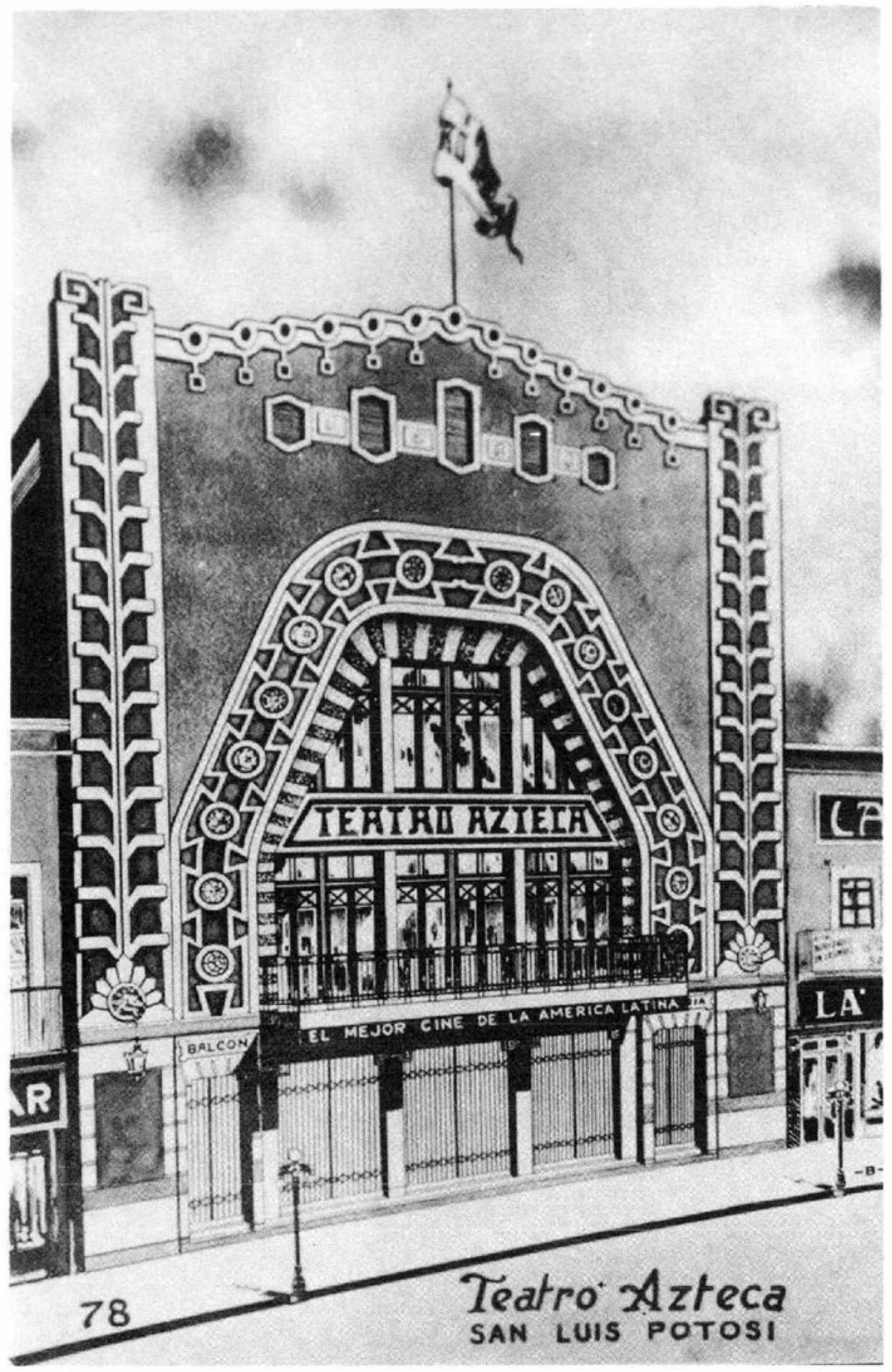

Figura 3. San Luis Potosi. Teatro Azteca. Hoy demolido porque rompia la homogeneidad de las construcciones, mas no se supo como sustituirlo. 
DOI: http://dx.doi.org/10.22201/iie.18703062e.1982.50\%20Tomo\%202.1150

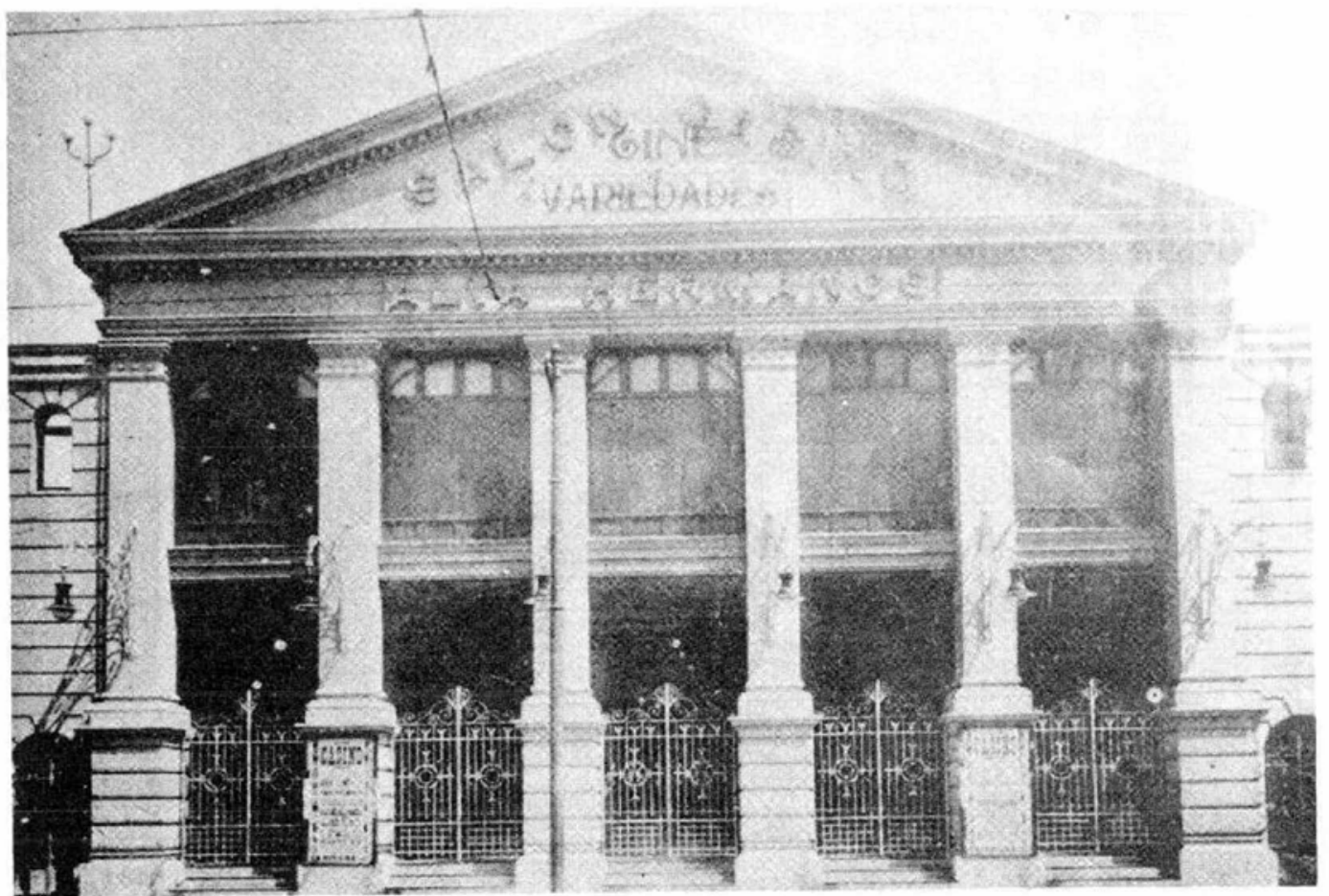

Figura 4. México, D. F. Cine Casino, hoy desaparecido, estuvo situado en las calles de Guerrero. 
DOI: http://dx.doi.org/10.22201/iie.18703062e.1982.50\%20Tomo\%202.1150

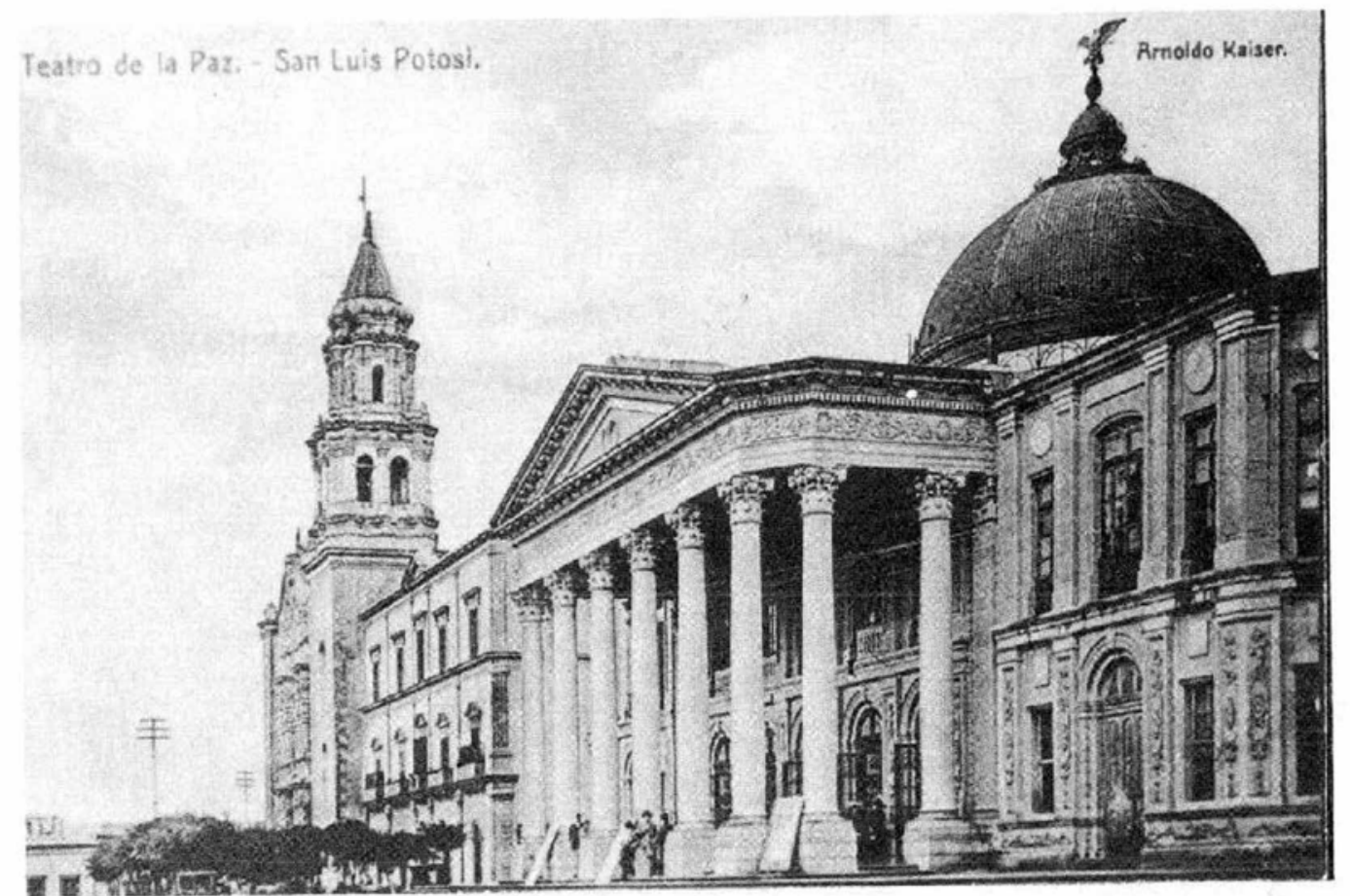

Figura 5. San Luis Potosí, S. L.P. Teatro de la Paz. Supuestamente los carruajes debían atravesar el pórtico para evitar a los asistentes las inclemencias del tiempo. 


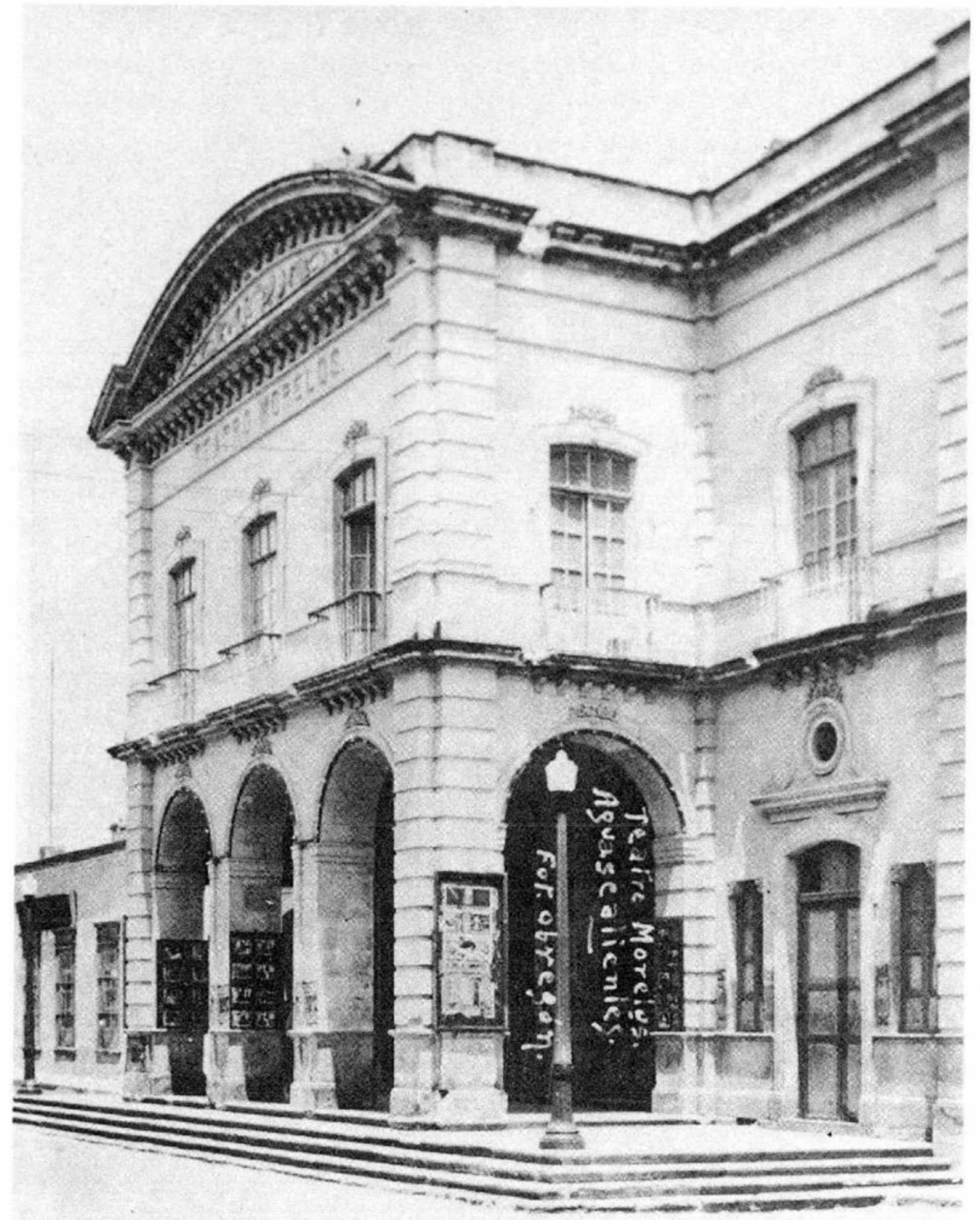

Figura 6. Aguascalientes, Ags. Teatro Morelos, el pórtico fue reducido al igual que el teatro de la $\mathrm{Paz}$, de San Luis Potosí, para convertirlo en un clemento decorativo. Obsérvese la ausencia de marquesina, elemento de carácter exclusivamente cinematográfico. 


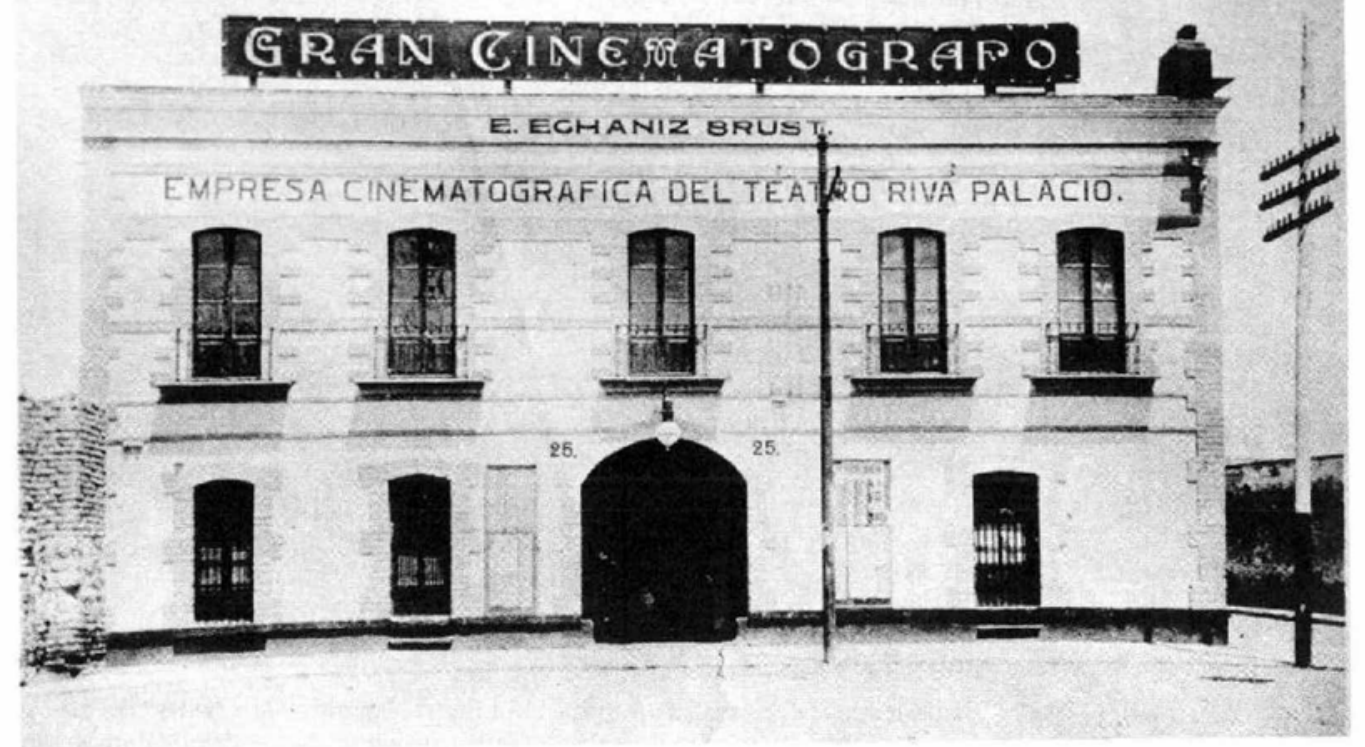

Figura 7. México, D. F. Teatro Riva Palacio, en las calles de Ayuntamiento, hoy X.E.W. Fue una casa adaptada. A partir de 1905 ofrecia exclusivamente funciones cinematográficas.

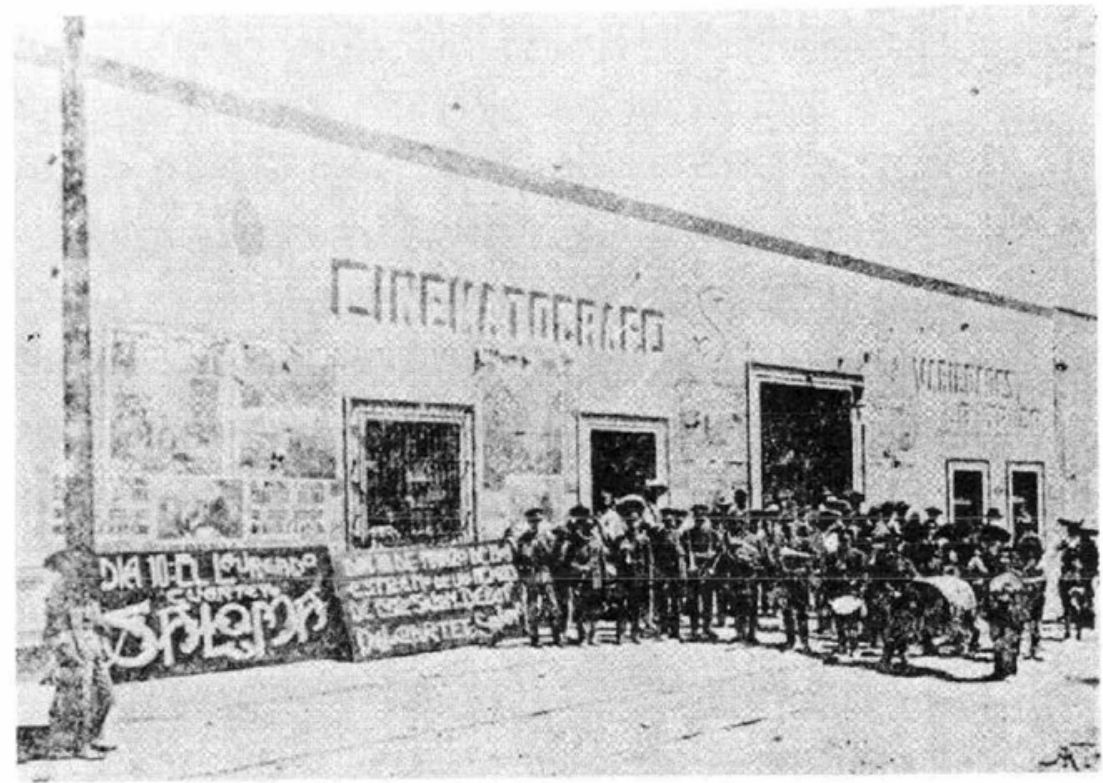

Figura 8. Casa adaptada por Federico Bouri en Aguascalientes, Ags., para su cinematógrafo "Vista Alegre". Él y su familia vivian en la parte trasera del edifico. 


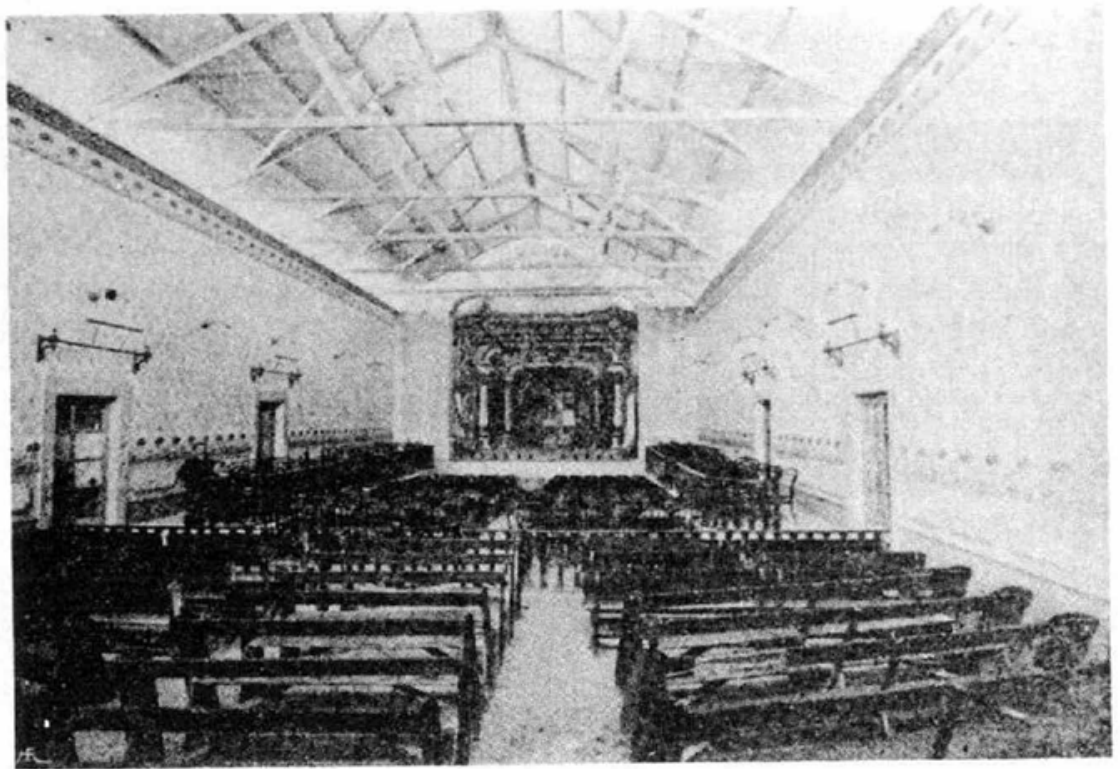

Figura 9. Interior del cine "Vista Alegre", el patio sirvió para sala de proyección, obsérvese la modificación hecha por Bouri para construir el escenario, asimismo las puertas de las dependencias que comunicaban con el patio y en la que el público veia diversiones adicionales después de la función.

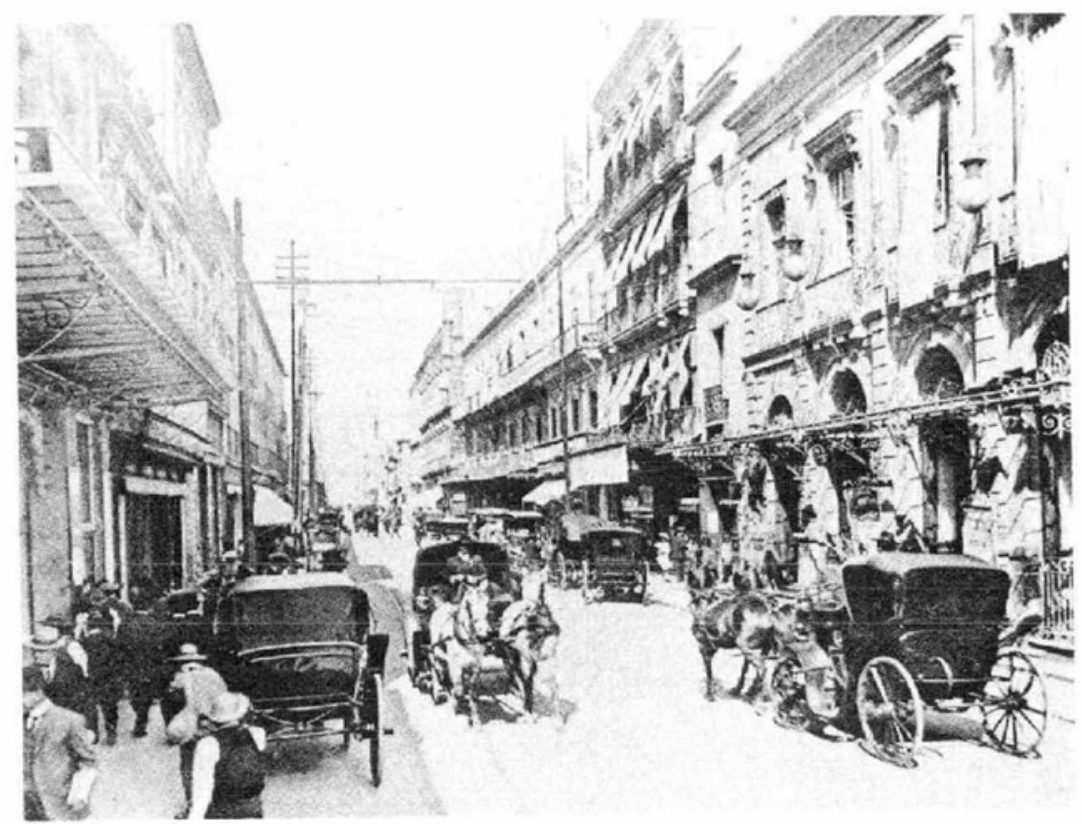

Figura 10. México, D. F. A la derecha, el Salón París, en la hoy calle de Bolivar, carecía de vestíbulo y pórtico, como la mayoria de los primeros cines. Una cortina gruesa cubría la puerta para evitar la penetración de la luz. 


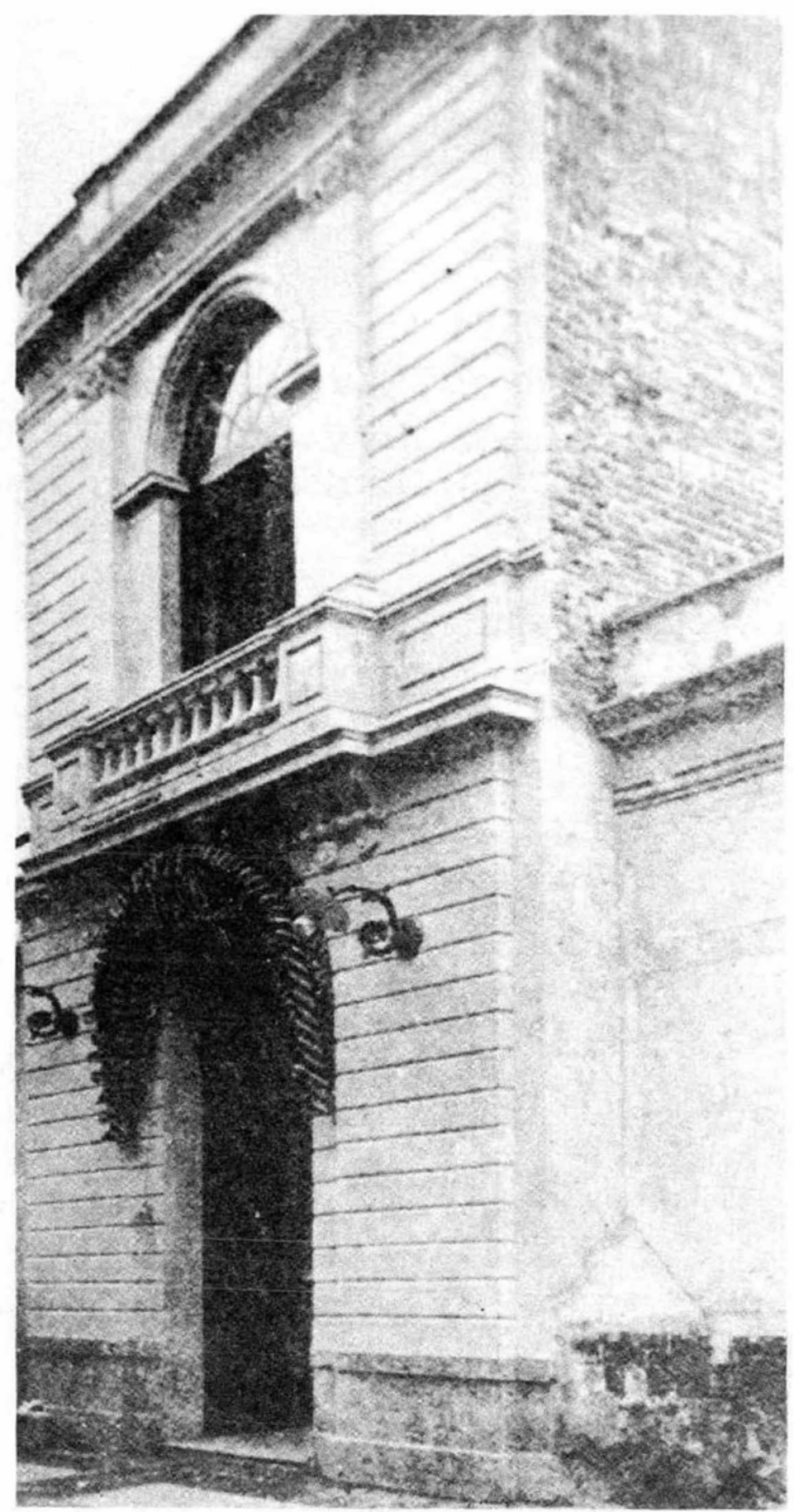

Figura 11. México, D. F. Fachada de la Academia Metropolitana. 
DOI: http://dx.doi.org/10.22201/iie.18703062e.1982.50\%20Tomo\%202.1150

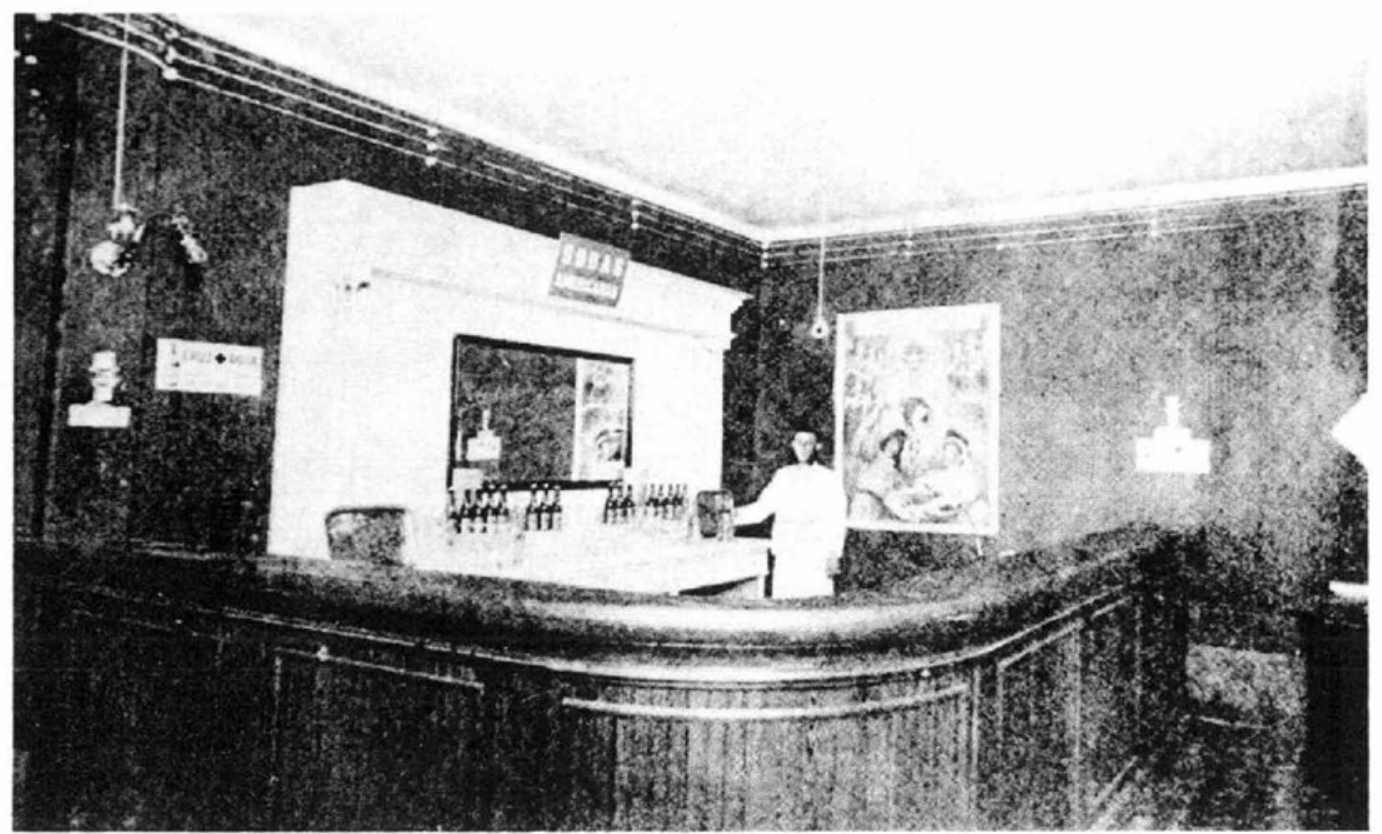

Figura 12. El "Buffet" o expendio de refrescos y dulces de la Academia Metropolitana.

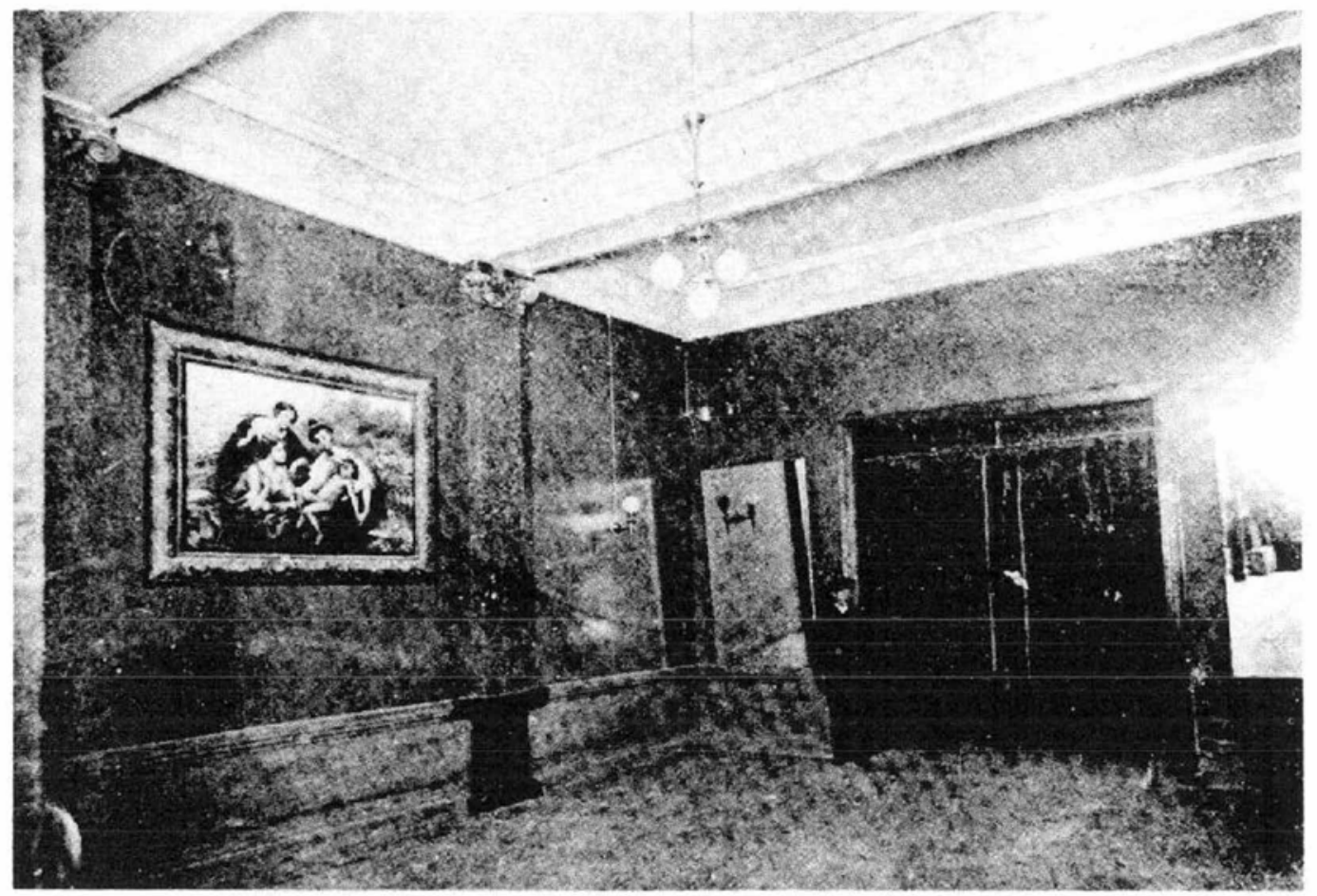

Figura 13. Vestíbulo de la Academia Metropolitana. 
DOI: http://dx.doi.org/10.22201/iie.18703062e.1982.50\%20Tomo\%202.1150

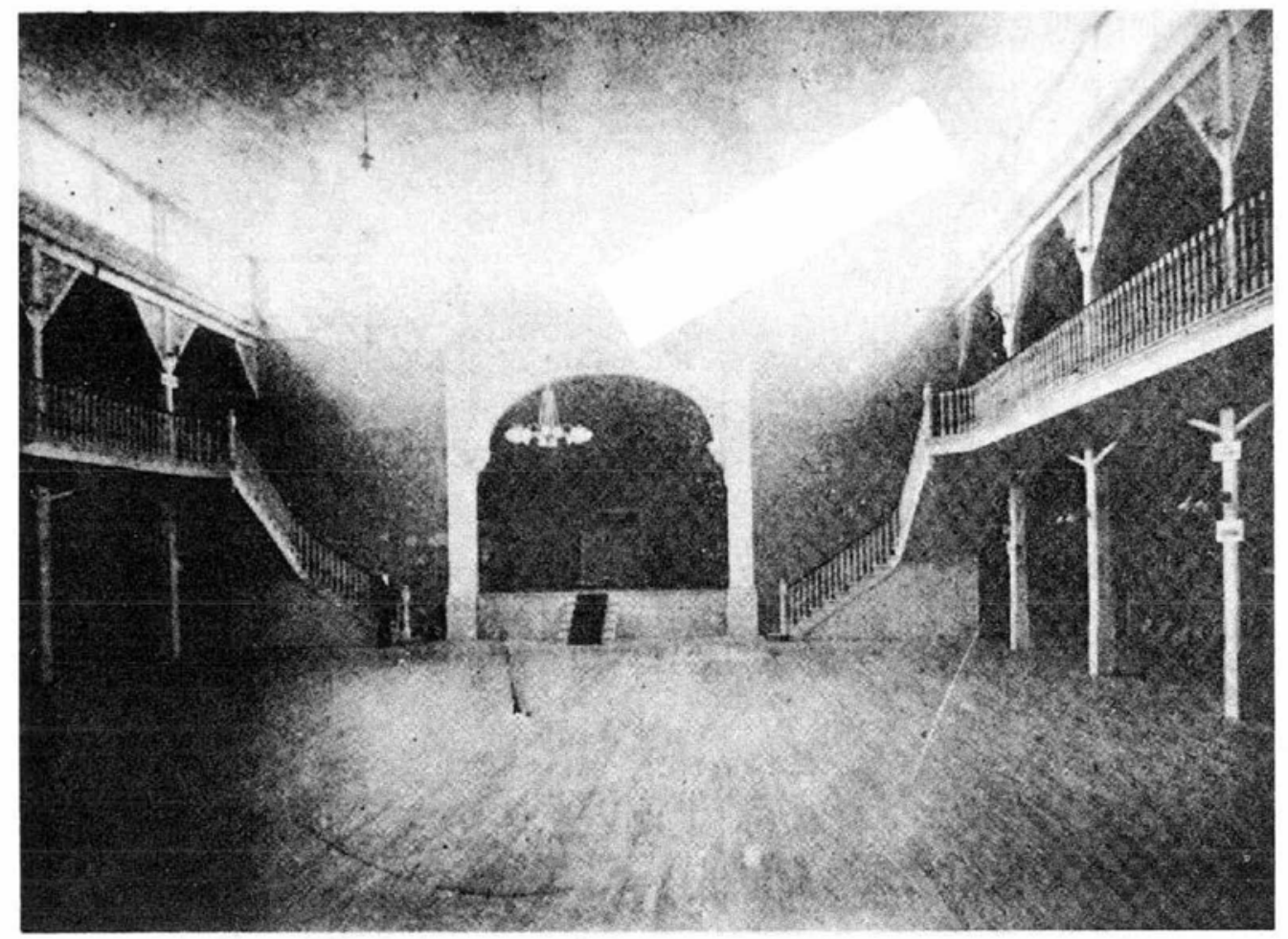

Figura 14. Luneta o patio de la Academia Metropolitana. 
DOI: http://dx.doi.org/10.22201/iie.18703062e.1982.50\%20Tomo\%202.1150

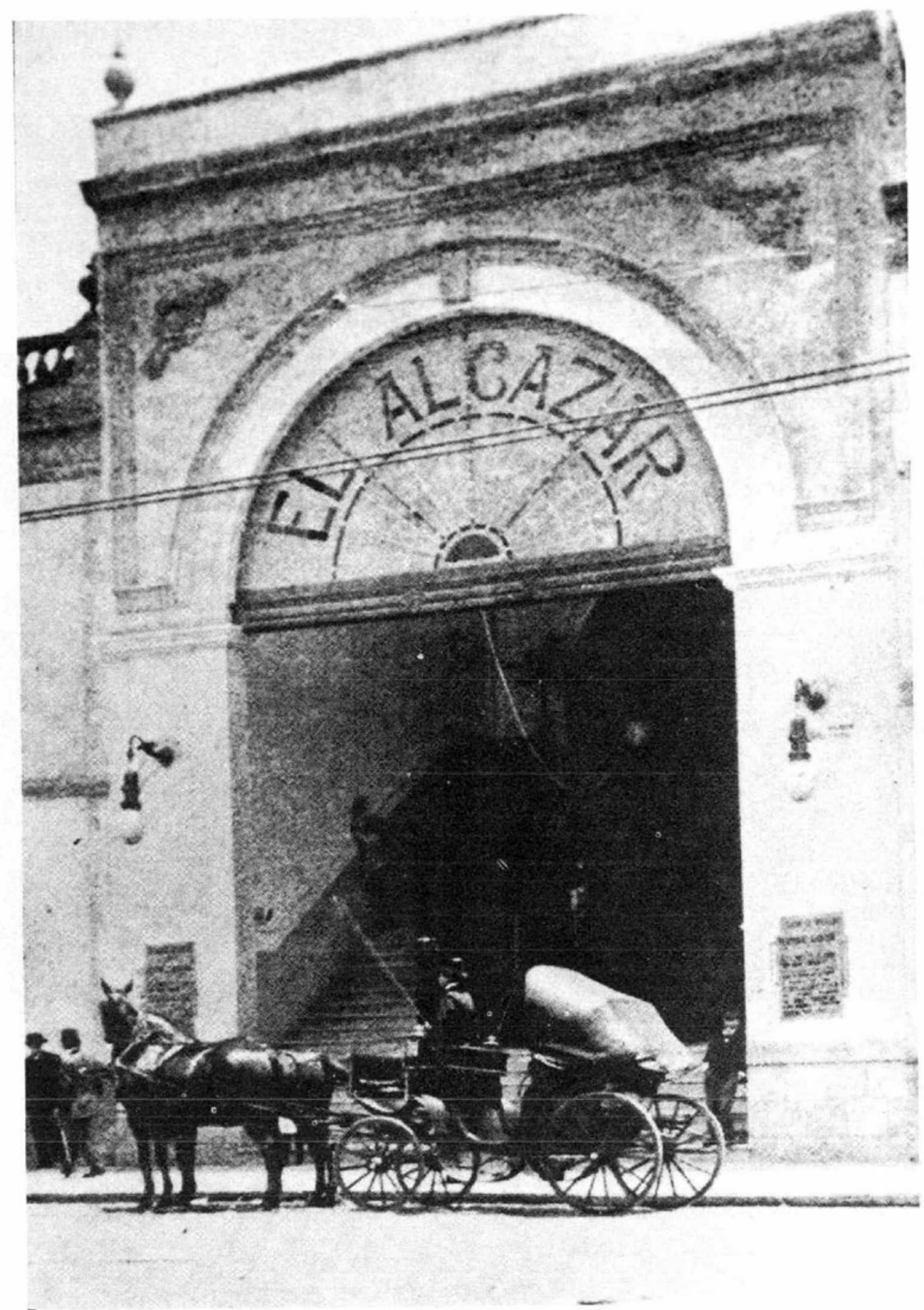

Figura 15. México, D. F. Fachada del Teatro Alcázar. 


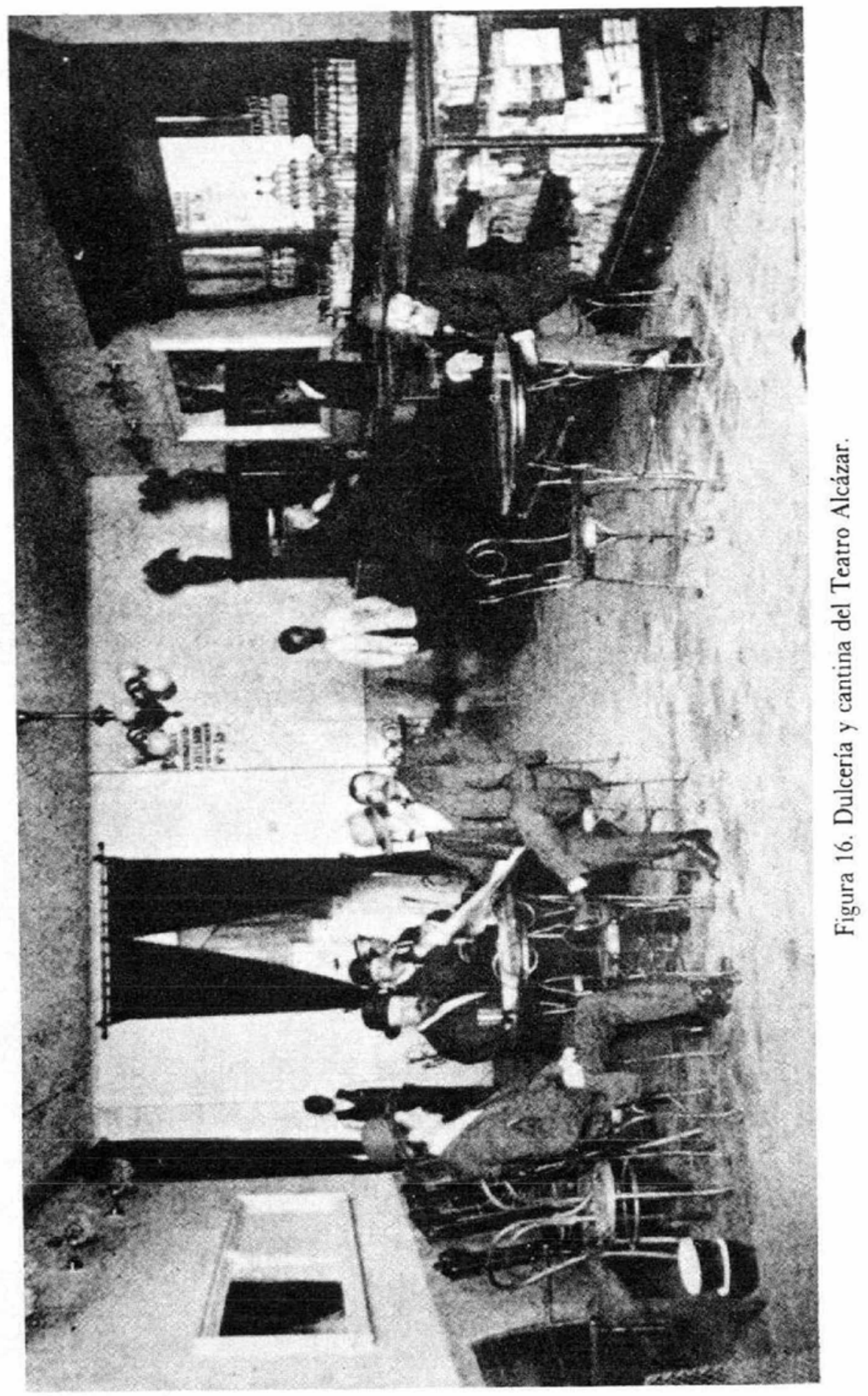


DOI: http://dx.doi.org/10.22201/iie.18703062e.1982.50\%20Tomo\%202.1150

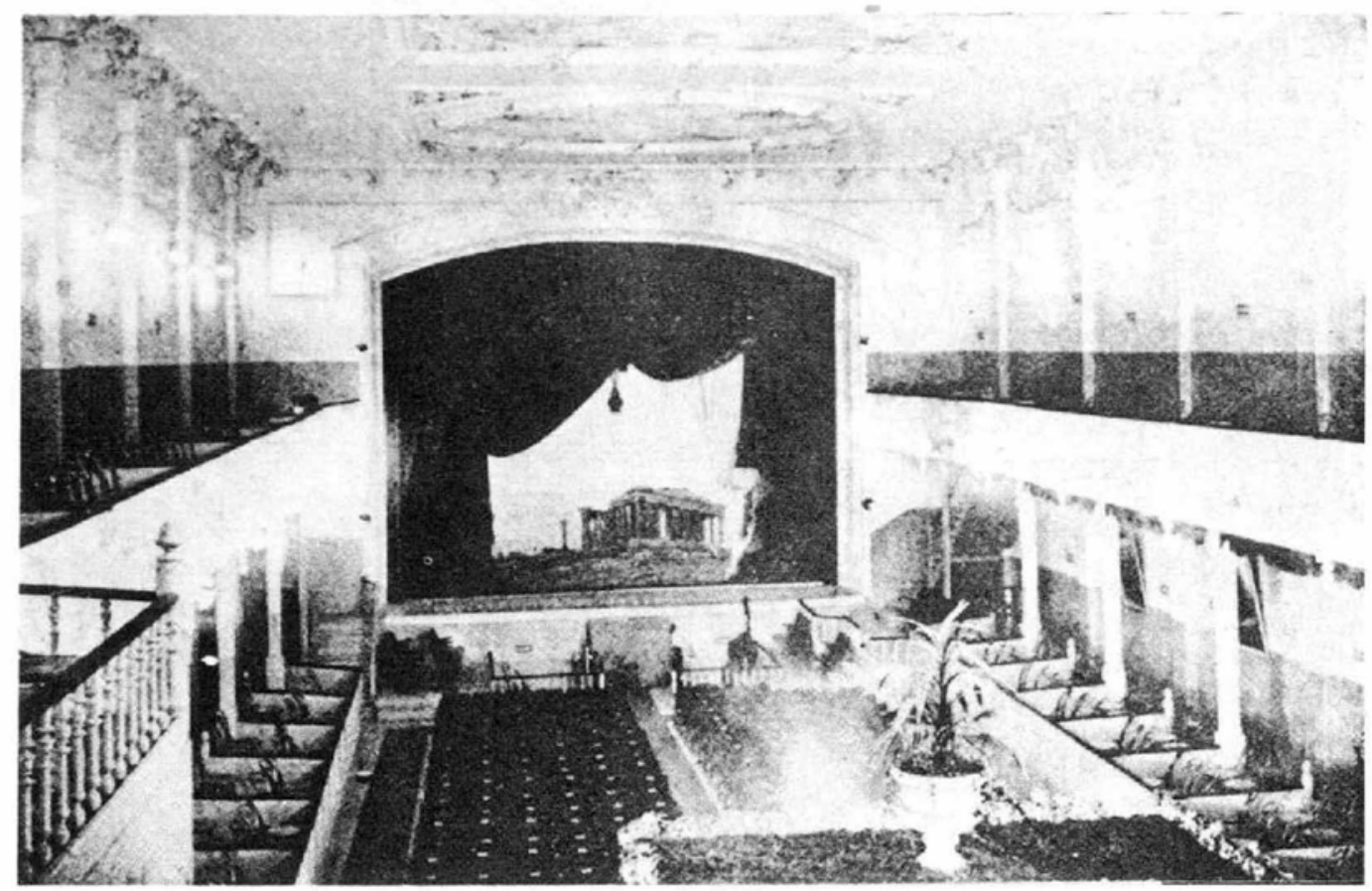

Figura 17. Interior de "El Alcázar". Destacan los palcos laterales y la dimensión del escenario, de tradición teatral.

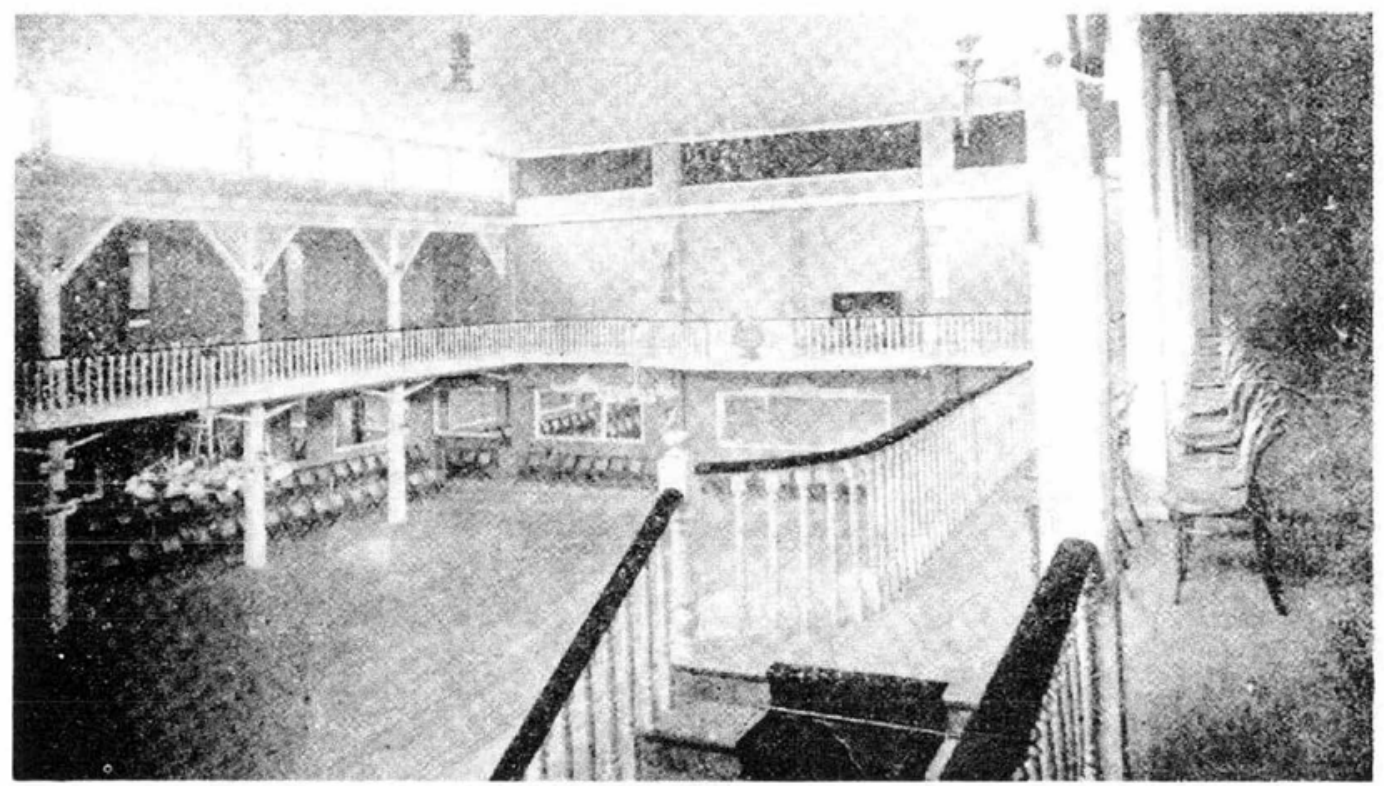

Figura 18. México, D. F. La Academia Metropolitana, sin caseta de proyección. 

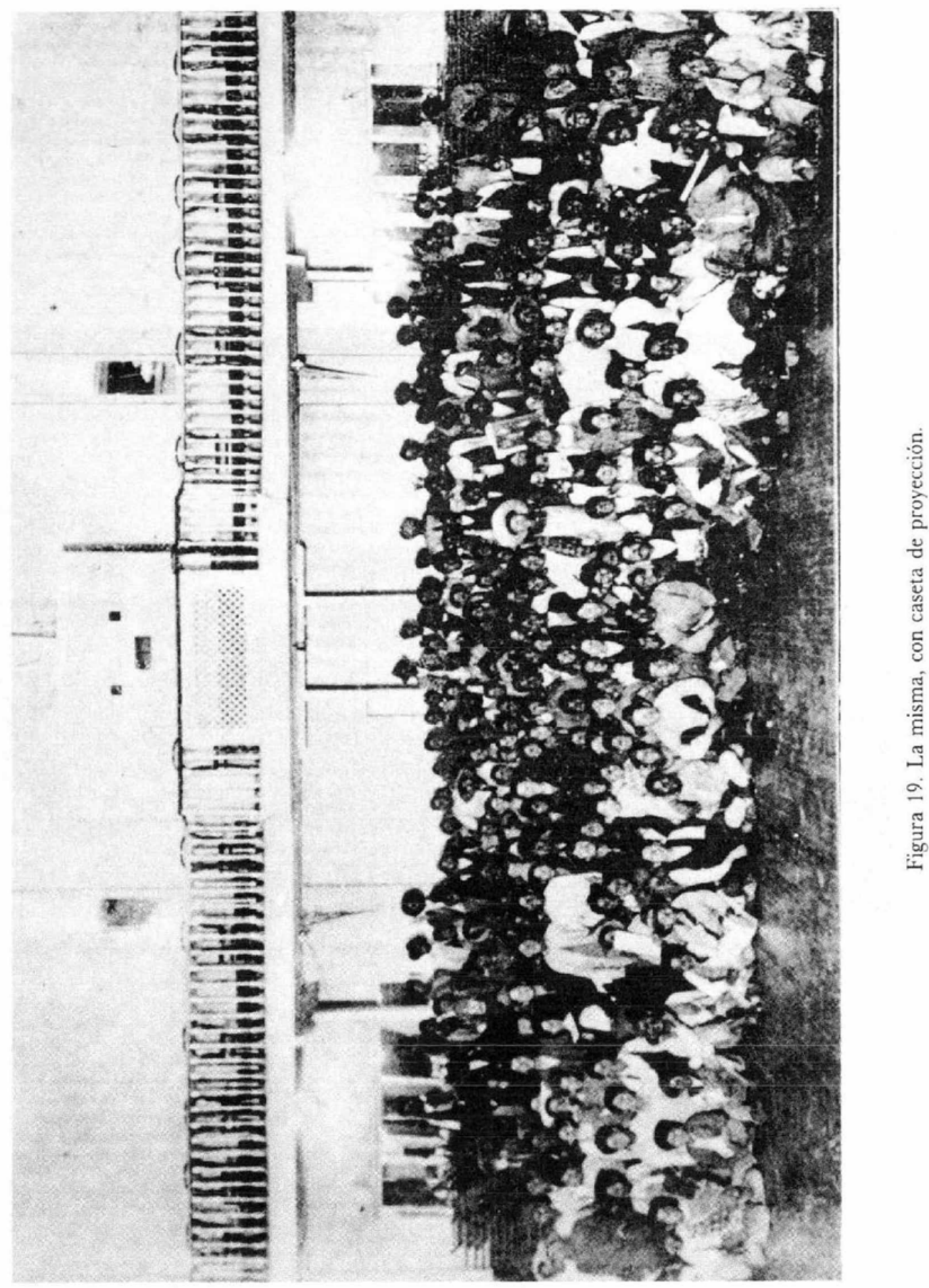
DOI: http://dx.doi.org/10.22201/iie.18703062e.1982.50\%20Tomo\%202.1150

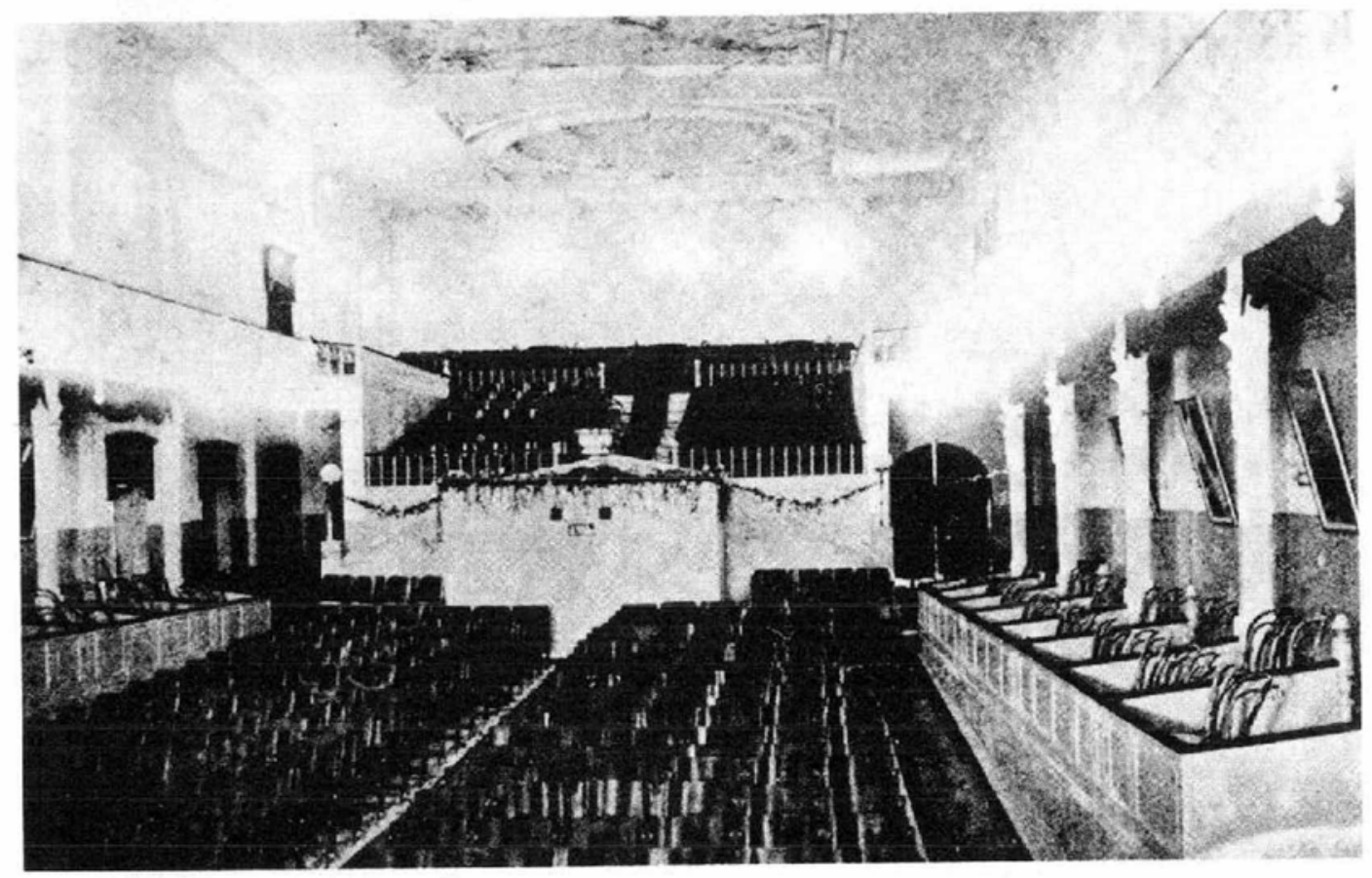

Figura 20. México, D. F. Interior del Teatro Alcázar. Obsérvese el esfuerzo de los arquitectos por integrar la caseta al conjunto del edificio. 